\title{
A method for improving farm practice: a case study of pugging
}

\author{
I.S. TARBOTTON ${ }^{1}$, M.S. PAINE ${ }^{1}$, M.E. WEDDERBURN ${ }^{1}$ and M. CARLYON ${ }^{2}$ \\ ${ }^{1}$ AgResearch, Ruakura Research Centre, Private Bag 3123, Hamilton \\ ${ }^{2}$ Dairy Farmer, Ohinewai, North Waikato
}

\begin{abstract}
Historically farmers made little distinction between farming for product or farming to maintain the physical resources for future generations but now have to demonstrate the latter. With this challenge, Federated Farmers, AgResearch, Livestock Improvement Corporation and Environment Waikato initiated study groups in the Waikato, linking farmers, scientists and policy agents. A case study of pugging (stock treading) management is used to demonstrate the group participatory process. The key stages in the group's development over time are explained. Throughout these stages, exchange of principles, experiences, ideas and data about pugging were aligned to the group's needs. Management guidelines to minimise pugging damage in both winter and spring were identified. The economic impact of pugging damage to paddocks was analysed at the farm level using UDDER. A comparative discussion of the group process compares the experiences of participants with published claims about study groups. Discussion of the group process calls for the need to develop methods for analysing group process.
\end{abstract}

Keywords: decision-making, farm system, monitoring, participatory process, pugging, resource management, study groups

\section{Introduction}

Participatory group approaches have successfully addressed complex farming systems and environmental problems when expert-driven approaches have failed (Amanor 1990; Campbell 1994; Engel 1991; Foote Whyte 1991; Okali 1994). These studies have also claimed that changes in farming practices are most likely when participants improve their appreciation of other participants' perspectives when operating in group settings. Often the detail of how to appreciate and work with others in groups is left largely undeveloped. This paper will discuss the working experiences of a group in north Waikato to outline the practical issues involved in using a participatory approach to align farming systems and resource management needs. Our experience with dairy farmers highlighted the need to reconsider the generally accepted notion of participation in relation to farmer control of the group process. "Process" refers to the way a group changes over time in terms of membership and collective identity (Brown 1988). "Participation" is a means by which group members gain entry and actively contribute to the collective work of the group.

As biophysical researchers we have found it difficult to adopt some of the participatory processes written about in the literature, but learnt valuable lessons through errors in managing the process.

National and international market signals increasingly link food production with responsible environmental resource management (Laban 1994). Often, more complex farming systems are required to make this link, with corresponding greater demands on the farmers who manage these systems. Where previously farmers made little distinction between farming for product or farming to maintain the status of natural resource for future generations, they now have to demonstrate the latter. A programme was established in 1994 to investigate the development of farming practices that addressed market and resource management needs from our farming systems. A literature review identified the participatory approach as the preferred approach to developing these types of farm practices. Group participants share the tasks of formulating problem statements, specifying the variables and selecting the methods of data collection, analysis and interpretation.

The programme was a joint endeavour by Federated Farmers, AgResearch, Livestock Improvement Corporation and Environment Waikato. A central component was a study group to link farmers, scientists and policy agents in the development of farming practices. The group was charged with sharing knowledge and experience to enable the implementation of management practices to link production with resource management goals. The study group consisted of eight dairy farmers, a LIC consulting officer, an Environment Waikato field officer, a farm system analyst and a soil scientist. The group met every two months to identify issues and evaluate solutions. The meetings were run by a facilitator whose role was to maintain momentum and 
follow pre-set meeting themes. The study group process relies on the study of knowledge and experience of all participants.

This paper demonstrates the use of the study group process and documents the farm management practices identified. Discussion opens with an introduction to the process used in the study group to build farm practices. A brief chronological outline of learning experiences in the group is provided before discussing the emergent principles derived from these experiences. The paper concludes with a critique of the participatory process.

\section{The study group approach}

A six stage process was used to establish the study group:

- programme leaders identified critical group roles;

- organisations and individual farmers enlisted into the group;

- a problem identification stage searched for common issues among participants;

- interactive learning between science and farmers, hence the name "study group";

- the group took action on selected issues by changing farming practices like stock movements and monitoring their impacts;

- an evaluation stage assessed the effects of changes in farm practice and changes in group interaction with respect to the programme goal.

The last four stages ran concurrently.

\section{Case study in chronological order}

This section reports on critical periods in the sequence of meetings spanning the establishment of study groups to the farmer-led public presentation of group achievements. At each date the group progress on content is outlined followed by emergent principles relating to the process.

\section{March 1995 - searching for a common issue}

The group initially struggled to focus on a theme which encompassed farm production and resource management. Weighing of dairy heifers was an issue the group worked on, compared information and discussed response action.

In the second group meeting the issue of pugging was first raised. Pugging damage of soil and vegetation is routine on dairy farms and, more recently, on sheep and beef farms where cattle numbers have increased. Farmers have long suspected that this damage is not good for their land, although few have documented adverse impacts.

\section{Group process}

Most group members were meeting each other for the first time. Members possessed only a limited understanding of the programme purpose. It was important to clarify the group purpose and desired outcomes, and it was then up to the group how these were approached. A search for issues fitting the group's purpose was a prominent feature of this stage. A topic was chosen (heifer weighing) which served as a simple example of sharing farm data and comparing with science target weights.

\section{May 1995 - investigation}

In response to study group farmers wanting information on pugging damage, a soil pedologist ran a workshop, at which soil sods were examined and a general scale of pugging damage drawn up (Appendix 1). Soil texture was initially assessed at the soil surface, then holes were dug to look at the soil's physical structure.

Scientific trial information was provided at this time which quantified production loss caused by pugging (Ledgard et al. 1996). The farmers felt that the pugging damage scale was not very practical, as it separated surface pugging from compaction. They wanted a single scale that integrated topsoil compaction, surface pugging and vegetation cover. One farmer in particular followed this through and used a 10-point grading system to assess pugging. The farmers concluded that their goal was to prevent pugging damage rather than repair it.

\section{Group process}

Enthusiasm for the pugging issue escalated with the start of a wet winter. As this new issue was discussed the group reached the decision that a specialist researcher in this field was required to present trial results and explain the importance of pugging damage to soils. The farmers did not care about the group process but instead were focused on the meeting content and outcomes.

\section{June 1995 - monitoring}

Monitoring soil, vegetation and animal condition was instigated in order to determine when management changes were to take place. Farmers diligently monitored pugging during winter 1995 to determine when to move cows from paddocks to resilient surfaces. They identified paddocks they believed to be more or less vulnerable and set their rotations accordingly. They monitored the state of the paddock when animals were present and used this information to aid decisions on when to move 
them. The weather, particularly frequency of rain, made decision making and management practice dynamic, particularly when frequent rain meant even those paddocks designated more resilient were damaged. No rigid standard was set by the group because each individual had to make a decision based on specific circumstances. To aid decision making a workshop was held where farmers outlined the observations they used to monitor the management strategies that could be used, the actual management practices and the implications of use on cows, farmer, soil and vegetation (Table 1).

\section{Group process}

Monitoring of pugging was a common action by group farmers over this period. The participatory approach allowed individuality and adoption of management practices suited to each situation. These could all be presented and compared at group meetings.

\section{August 1995 - application of monitoring}

\section{Economics}

It was considered important to quantify how important pugging damage is economically for a study group dairy farm. One farmer attempted to quantify the pugging in each break or paddock on his farm after grazing, by visually estimating pugging damage. He estimated $10 \%$ of his farm was damaged. A simulation model (UDDER) calculated the loss in production returns to the farm, based on this $10 \%$ damage, and using the results from research trials on lost pasture production from badly pugged soils (Ledgard et al. 1996). UDDER estimated that the farm would have grown $400 \mathrm{~kg} \mathrm{DM} / \mathrm{ha}$ less pasture in a year, which equates to one cow condition score, a loss in milk production valued at $\$ 8000$, or the amount of feed normally made into silage. This information reinforced farmers' belief in use of an accurate quantitative scale for evaluating pugging damage.

Table 1 The results of a workshop at which the group documented the understanding, management and outcomes developed to prevent winter pugging. (Note example is in shaded areas follow from left to right.)

\begin{tabular}{|c|c|c|c|c|}
\hline Observations & Management strategies & Management options & Overcoming implications & Outcomes \\
\hline $\begin{array}{l}\text { 1. Soil condition before grazing } \\
\text { in the wetter months of: } \\
\text { June, July, August, Septem- } \\
\text { ber, October. } \\
\text { 2. Soil moisture content: } \\
\text { - How soft is the ground? } \\
\text { - Is the area water logged? } \\
\text { - Is water standing on the } \\
\text { surface of the ground? } \\
\text { 3. Know the topography of the } \\
\text { paddock. The above three } \\
\text { give you the base paddock } \\
\text { information and should be } \\
\text { used in conjunction with } 4 \\
\text { and } 5 \text {. } \\
\text { 4. Weather, particularly rainfall } \\
\text { previous, actual and } \\
\text { forecast. Wind speed and } \\
\text { direction and in combination } \\
\text { with actual rainfall. } \\
\text { 5. Grass colour, i.e, dirt on } \\
\text { grass within the area being } \\
\text { grazed going beyond ac- } \\
\text { ceptable levels. }\end{array}$ & $\begin{array}{l}\text { 1. Recognise the potential for } \\
\text { damage. } \\
\text { 2. Grade paddocks according to } \\
\text { their susceptibility to } \\
\text { damage. } \\
\text { Followed by one or more of } \\
\text { the following options: } \\
\text { a) Implement On/Off grazing } \\
\text { using: } \\
\text { Races, cow sheds, dry } \\
\text { peat land or a sacrifice } \\
\text { paddock. } \\
\text { b) Grazing off farm, or carry- } \\
\text { ing feed to cows on a pad. } \\
\text { c) Decrease stocking pres- } \\
\text { sure by speeding up rota- } \\
\text { tion short term. Increase } \\
\text { the area cows are grazing, } \\
\text { e.g., not break feeding or } \\
\text { use of larger breaks. }\end{array}$ & $\begin{array}{l}\text { 1. On/Off grazing: This will } \\
\text { minimise damage and is: } \\
\text { convenient, beneficial, } \\
\text { cheap and allows easy } \\
\text { feed rationing. } \\
\text { Implications: Cows get sore } \\
\text { feet, there is damage to } \\
\text { races, possible loss of cow } \\
\text { condition, damage to gate- } \\
\text { ways and fences, and it is } \\
\text { labour intensive. } \\
\text { 2. Grazing either off farm or on } \\
\text { a feed pad: no pugging. } \\
\text { Implications: Going off farm } \\
\text { is expensive, it depends on } \\
\text { availability and results in loss } \\
\text { of control of cow condition } \\
\text { and stock management. } \\
\text { On farm pad has a high } \\
\text { labour input of feeding, } \\
\text { requires buying or making } \\
\text { large quantities of feed, } \\
\text { effluent has to be spread, } \\
\text { loss of fertility return to the } \\
\text { paddocks, capital cost. On } \\
\text { farm there is a loss of } \\
\text { pasture control resulting in } \\
\text { rank feed. } \\
\text { 3. Speeding up rotation: Short } \\
\text { term for } 1 \text {-2 days. Early in } \\
\text { winter it is a quick short term } \\
\text { solution. } \\
\text { Implications: Uses too much } \\
\text { feed. Eating into reserve feed } \\
\text { is the key point. Have } \\
\text { reduced grass cover. }\end{array}$ & $\begin{array}{l}\text { Put in longer hours and be } \\
\text { prepared to change priority on } \\
\text { your time. } \\
\text { Short-term take care and shift } \\
\text { cows slowly; long-term do more } \\
\text { repairs and maintenance. } \\
\text { Keep yard clean and free of } \\
\text { debris. } \\
\text { Use a foot bath and put copper } \\
\text { sulphate on the races or on } \\
\text { mats, separate and treat cows } \\
\text { with severely sore feet. } \\
\text { Restrict the movement on races } \\
\text { to a small area. } \\
\text { Research the cost of grazing off } \\
\text { farm and supplements on farm. } \\
\text { Forward planning to control } \\
\text { pasture at home. }\end{array}$ & $\begin{array}{l}\text { Time well spent, short-term there } \\
\text { was less cost, fewer long-term } \\
\text { negative effects. The problem } \\
\text { was perceived to be greater than } \\
\text { that which eventuated. No effect } \\
\text { on cow condition. } \\
\text { Success - no permanent dam- } \\
\text { age, sore feet healed quickly } \\
\text { without long-term negative } \\
\text { effects. The problem was } \\
\text { perceived to be greater than } \\
\text { that which eventuated. No effect } \\
\text { on cow condition. } \\
\text { Good result short term, costly } \\
\text { and high risk long term. } \\
\text { Increase the area: Keep it short } \\
\text { term, a few days at a time, and } \\
\text { consider nitrogen as an option. }\end{array}$ \\
\hline
\end{tabular}




\section{Management implications}

\section{Winter}

As a result of farmers assessing pugging during the 1995 winter, they generally moved stock earlier than formerly practised to minimise soil damage. This practice created its own problems, including:

\section{Concerns}

- Farmer stress: particularly concerns about underfeeding stock, causing sore feet to cows, and the increased workload associated with monitoring paddock condition.

- Risks to farm performance: primarily the risk to seasonal production if cows entered the new season in poorer condition, and if feed deficits occurred in spring.

\section{Realities}

- Farmer stress declined in spring as stock recovered quickly from sore feet, and the pressure declined to move stock early to avoid pugging. The group found that cow condition improved gradually, owing to better pasture production achieved by the change in winter management.

- The farmers experienced the benefits of early stock movement and greater awareness of paddock condition at spring time, when pasture not pugged during the winter was dense and healthy, resulting in better growth.

\section{Spring}

Developing management to control winter pugging damage alerted farmers quickly to the unique pugging problems associated with spring management. During the 6-8 weeks of intensive spring calving, typically there are extra mobs of cattle, each mob with different feed and management requirements and different behaviour patterns. These factors influence the risk of pugging. The aim was to record management practices around calving and early lactation which minimise pasture damage and pugging and maintain optimum animal production in the short and the longer term.

Some farmers have fewer than four mobs of cattle during calving, but Drys, Springers-Calvers, Colostrum and Milkers represent the most common mob structure. In general, the dry cows are the easiest mob to manage and the cows still producing colostrum are the most difficult.

Because the spring calving period puts additional constraints on time, any pugging prevention management needs to be simple and take minimal additional time.

At this time of year, farmers are often on their second round of grazing during wet winter conditions.
This means that pastures are more susceptible to damage and risk of pugging is higher. This risk varies according to the season and the characteristics of the paddock. A workshop was held with farmers to elicit the requirements for managing pugging in spring (Table 2).

\section{Group process}

The combined effort of farmer monitoring and the group systems analyst using a computer model allowed a realistic pugging situation to be modelled to show the affect it can have on the farm system. This was a demonstration of the strength of combined effort making much better progress than any of the individuals could, and it helped to bring the group together.

\section{November 1995 - group at risk}

At this stage the group had completed its work on pugging and was in the peak production season. A loss of group direction and focus put the group establishment period at risk. To help the group overcome this stage an external facilatator ran a brainstorming workshop to generate issues relating to resource management and farm production as well as external factors or expectations imposed on the farm.

\section{Group process}

Different interpretations of the pugging issue had not been picked up and so the researchers thought it could lead onto run-off and non point source contamination of water quality, but farmers did not see water as an important issue to their farm systems at that time.

Record keeping was also discussed but no real progress made. The group's continuity and direction were slipping away, putting the group at risk. An external facilitator was brought in to help the group see the big picture relating to resources coming onto and going off the farm.

\section{May 1996 - group field-day}

At the group field-day held 15 months after the group was established all the members had come to the point that it was clear that there was a message to be promoted. Three farmers as keynote speakers emphasised the group's message of farmer experience, supported by short presentations by the researchers.

The successful field-day was a high point for the group. A brief questionnaire was filled in by the audience and responses were encouraging, as was the direct informal feedback from the public.

\section{Group process}

By this stage the group was confident enough in the progress it had made to hold a farmer-led public fieldday. Attendance and presentations were good, the farmer 
Table 2 The results of a workshop at which the group documented management to avoid spring pugging, on a mob basis.

\begin{tabular}{|c|c|}
\hline $\begin{array}{l}\text { Springers-Calvers } \\
\text { The cows in this mob will need more space and more feed than the } \\
\text { dry cows. }\end{array}$ & $\begin{array}{l}\text { Management options } \\
\text { Not recommended to hold cows onto a yard if they are close to calving. } \\
\text { Preferable to calve in dry paddocks where cows have more space and better } \\
\text { conditions for calving. This is thought to improve cow health and prevent } \\
\text { mastitis, improve calf survivability and help prevent mix ups in calf } \\
\text { identification. } \\
\text { Farmers may opt to stand off the bulk of this mob at night if conditions } \\
\text { are wet, but may leave those cows that are close to calving on the paddock. }\end{array}$ \\
\hline $\begin{array}{l}\text { Colostrum cows (calved but cannot be milked into vat) } \\
\text { The risk of pugging is greater from these cows and they can be } \\
\text { difficult to manage. Cows that have recently calved tend to be restless } \\
\text { and unsettled (seeking calves). They can damage pastures badly as } \\
\text { they walk the fences or hang around the gate. Management techniques } \\
\text { are needed that will settle these cows as soon as possible. }\end{array}$ & $\begin{array}{l}\text { Management options } \\
\text { Let them 'stand-off' voluntarily into the race. Some farmers leave the gate to } \\
\text { their paddock open so that these cows can walk the races rather than the } \\
\text { paddock. It is preferable if they are not allowed near the calves, as this will } \\
\text { slow the settling period. } \\
\text { - Use a fresh paddock for this mob each day if: } \\
\text { - it fits the management system } \\
\text { - if there are small numbers } \\
\text { - Run the colostrum cows with the milkers. They will settle quicker and } \\
\text { there will be one less mob to manage. This probably suits smaller herds } \\
\text { with conscientious operators best, as there is a risk to milk quality if the } \\
\text { colostrum gets into the vat. Some operators prefer to draft at the shed or } \\
\text { during milking and milk the colostrum cows separately, to avoid milk } \\
\text { quality problems. } \\
\text { Rotate the colostrum mob ahead of the milkers, to avoid one or two paddocks } \\
\text { severely damaged by a mob. }\end{array}$ \\
\hline $\begin{array}{l}\text { Milkers } \\
\text { The nutrition risk is highest with this group as their intake needs are } \\
\text { the highest among the mobs. Their intake needs are } 2-3 \text { times that } \\
\text { of dry cows. Underfeeding creates a risk of poor conception rates } \\
\text { (more empties) and reduced milk production. Nutrition must be good } \\
\text { as they approach mating. } \\
\text { - Standing-off risks are greatest with the milkers } \\
\text { - reducing grazing time } \\
\text { - reduced intake if grass is short }\end{array}$ & $\begin{array}{l}\text { Management options } \\
\text { Standing off (on-off grazing), carefully managed to: } \\
\text { - get high pasture intakes in a short period of time. This requires long } \\
\text { grass. } \\
\text { - reduce risk of lameness as for dry cows. }\end{array}$ \\
\hline $\begin{array}{l}\text { Dry cows } \\
\text { The winter management guidelines, in Table 1, apply to the dry cow } \\
\text { mob during the calving period. }\end{array}$ & \\
\hline
\end{tabular}

presentations being particularly well received. This was a high point for the group and a key stage in the sharing of a common focus with all group members.

\section{Practical issues for participatory approaches}

There are risks associated with programmes that leave the development of work content in study groups to emerge within the group - a muddling through design for the discovery of work. These risks are that the scope of work activities may remain within the comfort zone of most members, while neglecting the performance of some activities that are critical to attaining the programme's purpose. However, these risks are necessary if the programme is to muddle through towards aligning resource management and production goals. Programme leaders cannot hope to anticipate common needs, such as those that emerged as the wet winter took effect on the group's activities. Part of the group's enthusiasm for the collective construction of pugging management methods emerged from the very spontaneity of the wet winter events. A problem like the pasture effects from a wet season fostered cohesion in the group as part of an overriding need to take action on resource management in farming. Group cohesion was a consequence of the joint activities, not a precursor to performing joint activity. Furthermore, members required a problem of sufficient consequence to create uncertainty and a need for a change in farming methods. The researchers and professionals had another sort of need - to develop communication methods that 
interactively built the programme's content. Interactive communication can frustrate farmers and others if an individual can provide relevant content to the group but withholds information based on the perceived rules of an interactive process. By using routine evaluations that provided feedback and work planning activities, researchers and professionals discovered ways of enthusiastically using information on pugging for building management methods for reducing uncertainty about pasture damage and recovery.

In the group process an impasse has sometimes been reached and the group comes to a standstill. Then it has been necessary to draw back from the detail of the topic being worked on and review the initial group objectives as well as consider the bigger picture.

We will now look at where we have got to as a group and compare this with what the literature reported.

\section{Comparison with literature}

The literature lacked detail on the methods of establishing a participatory group but weighed heavily on the expected benefits. We found the establishment to be unexpectedly demanding and drawn out, but the eventual outcomes were beyond our expectations.

- The participatory approach was essential for progress on complex and obscure problem development; and included the focus on social interactions.

- The participatory approach ensured the alignment of science information to farm needs and scientific information that was inadequate to answer the group's questions. Increased farmer confidence aided in development and adoption of new farm practice.

- The literature on participatory approaches needs to expand discussion of how to overcome problems, especially with polarised groups that are willing to work together but may lack sufficiently common perspectives to build a cohesive group response to issues like resource management in farm production.

\section{Conclusion of the study process}

The study group began by bringing a diverse group of people together to make progress toward a broad goal. For this to occur trust needed to be established and also a confidence to debate and challenge each other's views, ideas and activities. This led to a higher shared goal that served to represent the key elements of each individual's goals.

As goals, concepts, language and tools were shared among the different professions in common work, a new sense of direction and insight emerged. This in turn created new practice that enhanced the group's relevance to resource and farm management needs and interweaved science into on-farm activity.

Group participation changed individual thinking, and individual participants challenged some organisations to actively support the programme's goal. The evaluation stage used in the study group process documented changes experienced by individuals but did not find corresponding published evidence to compare specific events with general principles of group process. Methods to analyse group process need to be developed, to allow some comparison between groups which have had varying success in achieving their goals.

\section{ACKNOWLEDGEMENTS}

We are grateful to the other members of the study group for their continual support especially Duncan Smeaton for his work on the Udder analysis and Mike O'Connor for trial information. We are also grateful to Technology for Business Growth for funding this study group research and MAF Policy for funding the field day. Thanks to Annie Perkins for facilitating the groups during the two pugging workshops and Peter Singleton for his pedology input.

\section{REFERENCES}

Amanor, K. 1990. Analytical abstracts on farmer participatory research. London, Overseas Development Institute.

Brown, R. 1988. Group Processes: Dynamics within and between groups. Oxford, Basil Blackwell.

Campbell, A. 1994. Participatory inquiry: Beyond research and extension in the sustainability era. Systems-oriented research in agriculture and rural development. International Symposium 21-25 November 1994, Montpellier, France, CIRAD-SAR.

Engel, P.G.H. 1991. Farmers' participation and extension. pp. 183-187 In Joining farmers' experiments: Experiences in participatory technology development. Ed. B. Haverkort, J. Van der Kamp and A. WatersBayer. London, Intermediate Technology.

Foote Whyte, W. 1991. Participatory action research: Introduction. pp. 7-15 In Participatory action research. Ed. W. Foote Whyte. Newbury Park, London, Sage Publications.

Laban, P. 1994. Accountability, an indispensable condition for sustainable natural resource management. Systems-oriented research in agriculture and rural development. International Symposium 2125 November 1994, Montpellier, France, CIRADSAR. 
Ledgard, S.F.; Thom, E.R.; Singleton, P.L.; Thorrold, B.S.; Edmeades, D.C. 1996. Environmental impacts of dairy systems. Ruakura Farmers Conference Proceedings.
Okali, C.; Sumberg, J. 1994. Farmer participatory research: Rhetoric and reality. London Intermediate Technology.

\section{Appendix 1}

\section{Evidence of compaction in topsoil}

Many land users have expressed their concerns about compaction damage to soils and in particular how to identify this damage and its extent. Below are some simple guidelines. These have been tested on a range of soils and a number of farms. Generally compaction leads to coarser and firmer soil structure, and loss of pores. Compaction affects the root environment in several ways.

(i) Water infiltration rates are low (or non existent).

(ii) Roots are physically impeded from exploring the whole soil for water and nutrient.

(iii) The soil has poor aeration which is detrimental to soil organisms and can result in some nutrients (such as nitrate and sulphur) being converted to gaseous forms and being lost from the soil.

\section{Simple guide to accessing soil compaction damage}

1. Unaffected

The whole of the topsoil is loose and easily crumbles into aggregates that are small, granular and porous. Roots have penetrated throughout the topsoil and are abundant. Worms are common.

\section{Slightly affected}

The upper part of the topsoil is granular and loose, but between about 10 to $15 \mathrm{~cm}$ some aggregates are larger and firmer. Roots are abundant throughout the topsoil but do not commonly penetrate the firmer aggregates.

3. Moderately affected

Larger and firmer aggregates are more common, particularly in the 10 to $15 \mathrm{~cm}$ zone where they can have a horizontal platy appearance. Roots are often observed to grow around rather than through the aggregates. The soil does not naturally crumble into small aggregates. Reddish stains can be seen along some root channels.

\section{Severely affected}

The soil surface is often lumpy and irregular, soil aggregates are coarse or absent, hard when dry, and soft and plastic when wet. Platy horizontal aggregates are common in the 10 to $15 \mathrm{~cm}$ zone. Roots are few below $5 \mathrm{~cm}$ and reddish stains can be seen along many root channels. The soil can be greyish in colour and may have an unpleasant smell when wet. There are few worms.

Scales:

Topsoil compaction $\underline{0}$ 20

Aggregates are coarse or absent, many reddish stains along root channels.

Surface pugging

$\underline{0}$

Surface is severely pugged and churned. Water sits in pug marks for days and the soil smells.
The soil is loose and crumbly. Aggregates are small and porous, many worms.

\section{0}

Slight flattening of the surface but hoof prints have not indented or disturbed the soil.
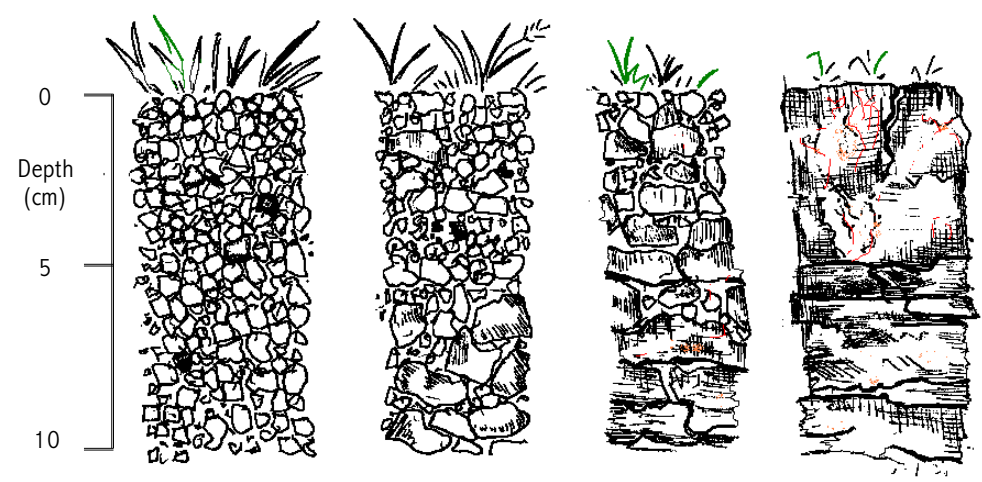
